\title{
Technology-Based Lesson Plans: Preparation and Description
}

\author{
Svetlana KUBILINSKIENĖ, Valentina DAGIENE \\ Institute of Mathematics and Informatics \\ Akademijos 4, LT-08663 Vilnius, Lithuania \\ e-mail: svetlana.kubilinskiene@@itc.smm.lt; dagiene@ktl.mii.lt
}

Received: November 2009

\begin{abstract}
A lesson plan is an important methodological component of the learning process. The key purpose of the article is to analyse the current situation and suggest how the information technologies can assist in the development of lesson plans, their accumulation and retrieval, thus ensuring their effective application. The authors disclose the problems of lesson plan creation and their description as well as make comparative analysis of information and lesson plan templates provided at learning objects storages. The authors identified the main components of lesson plans and their description, based on application of learning objects metadata standard model and the principles for improving the model elements as well as on the results of the analysis made, and proposed the templates for creating the technology-based lesson plans and their description. The development of lesson plans and descriptions will allow educators reuse didactic resources (lesson plans) as an effective learning tool. The storage of didactic resources will allow teachers to use the best practices, and the same learning objects in different learning scenarios.
\end{abstract}

Keywords: technology enhanced learning, lesson plan, lesson plans template, learning object, metadata.

\section{Introduction}

A lesson plan is an auxiliary teacher's work for preparing, organizing and conducting a lesson. By preparing for lessons a teacher writes a plan. It includes a topic, objectives, teaching structure, material for independent work of students, their work at separate stages, which students should be checked, etc. (Jovaiša, 1993). Rajeckas (1999) defines a lesson plan as a description of methodically-based lessons.

The lesson plan can be treated as one of the learning object examples. Any digital resource, to be used for teaching, most frequently for learning and applicable in other learning contexts, is usually considered as a learning object (LO) (Dagiene and Kurilovas, 2008; Wiley, 2000). In this paper, we shall use the notions of learning resources and learning objects synonymously (they are used like that in the European Learning Object Metadata Application profiles (LOM AP). In order that a resource might be used again, in another context, it should be related with the data describing the resource, the so-called metadata on the basis of which the work of LO storage is done: searching, generalization, 
importing into virtual learning environments and exporting out of them, assembling with other objects and so on (Jevsikova, Kurilovas, 2006).

Lesson plans were used in the education process long ago. Today's contemporary problem is how to present them in educational portals and resource repositories. The electronic learning process differs from the traditional way of teaching: one can use different tools (computer, e-mail, etc.), different types of resources (video or audio records, pictures and the like), work at different time and the like. The training process, in which the traditional teaching methods integrate internet teaching, is known as flexible learning, i.e., ever more popular learning model. Most important it is that this model allows reuse of learning resources (Tate, Hoshek, 2009).

The latest investigation of e-learning show that much time an effort are needed to develop new models, to improve the quality of learning objet and their usage (Slotkiené, 2009; Verbert and Duval, 2004; Verbert et al., 2005). On the other hand, it is no less important to illustrate how learning object are applied in the learning process.

Teachers are developing lesson plan that:

- stimulate teachers to take a deeper look at the everyday teaching process;

- encourage teachers to think of specific needs of each student: proper learning styles and methods are chosen for planning and specific needs of students are taken into account;

- there is a splendid basis for cooperation of colleagues: teachers can render their experience to beginners teachers, thus encouraging professional improvement;

- stimulate teachers to be innovators and propose new ways of teaching, to test new training aids and strategies for achieving better results;

- help teachers to be fit, to have more confidence in themselves and get the better of problems that may arise in the training process;

- assist in deepening teachers' knowledge and skills: careful lesson planning allows them to get an idea how and what is going on in reality.

Automated lesson planning systems are created however (Kouno et al., 2002; Cheon et al., 2002). These are mostly separate systems that do not follow to the metadata standards and are not meant for sharing the good teachers' experience. It has been noticed that learning object repositories and their search systems can realize the sharing of the good experience, but all that should be properly described.

A description of learning scenarios for sharing the good experience is presented in Roselli and Rossano (2006): the Experiences metadata model (EXM) of 8 categories has been proposed. The generated means enable us to transfer the description into the XML file based on the LOM standard.

The object of this research work is to form a model for lesson plan development and description on the basis of the analysis of scientific publications and storage data of learning resources, in order that pedagogues could reuse didactic resources (lesson plans) as an effective teaching and learning tool. Storage of didactic resources will allow sharing the good experience of different teachers, especially, using the same or similar learning object in different learning scenarios. 


\section{Exploration of Data in European Learning Objects Repositories}

A comparative analysis of information, given in European learning objects repositories, has been made (Table 1). Repositories of different size and purpose are surveyed, and in all of them lesson plans were found. There is one lesson plan repository among them "Virtual trip in the class", well known for the Lithuanian teachers. In Table 1, the analysis of repositories given below is presented (the numbers of repositories correspond to that present in the heading of the table).

Table 1

Information on lesson plans stored in repositories

\begin{tabular}{|c|c|c|c|c|c|c|c|c|c|c|}
\hline \multirow{2}{*}{$\begin{array}{l}\text { Information and representation form } \\
\text { Metadata elements }\end{array}$} & \multicolumn{10}{|c|}{ LO repositories } \\
\hline & 1 & 2 & 3 & 4 & 5 & 6 & 7 & 8 & 9 & 10 \\
\hline Identifier number & + & - & + & - & - & - & - & - & - & + \\
\hline Title & + & + & + & + & + & + & + & + & + & + \\
\hline LO Language & + & + & - & - & - & - & - & - & - & - \\
\hline Description & + & + & + & + & + & + & + & + & - & - \\
\hline Keyword & + & + & - & - & - & + & - & - & - & - \\
\hline Aggregation Level & - & - & - & - & - & - & + & - & - & - \\
\hline Contributors & + & + & + & + & + & + & + & + & + & + \\
\hline Metadata language & + & - & - & - & - & - & - & - & - & - \\
\hline Format & - & + & - & - & + & - & - & + & - & - \\
\hline Size & - & - & - & - & + & - & - & - & - & - \\
\hline Location & + & + & + & - & + & - & + & - & - & - \\
\hline Technical requirements & - & - & + & - & + & - & - & - & - & - \\
\hline Materials required & - & - & - & - & - & + & - & - & - & + \\
\hline Learning Resource Type & + & + & + & - & - & - & + & - & - & - \\
\hline Educational context & + & + & - & - & - & - & - & - & - & - \\
\hline Age Range & + & - & + & - & - & - & + & - & - & - \\
\hline Grade Level & - & - & - & + & + & + & - & + & + & + \\
\hline Typical Learning Time & - & - & - & - & - & - & + & - & - & + \\
\hline Educational Description/Objectives & + & - & - & - & - & - & + & - & - & - \\
\hline Assessment & - & - & - & - & - & - & + & - & - & - \\
\hline Prior Knowledge & - & - & - & - & - & - & + & - & - & - \\
\hline Expectations & - & - & - & - & - & - & + & - & - & - \\
\hline Scope & - & - & - & - & - & - & + & - & - & - \\
\hline Copyright and Other Restrictions & + & + & + & - & - & + & - & + & - & - \\
\hline Relation & - & - & + & - & - & + & + & + & - & - \\
\hline Classification (subject) & + & - & + & + & + & + & + & + & + & + \\
\hline Classification (Curriculum) & - & - & - & - & - & - & - & + & - & - \\
\hline \multicolumn{11}{|l|}{ Representation form of lesson plan } \\
\hline Attached Lesson plans file or link & + & + & + & + & + & + & + & - & - & - \\
\hline Web lesson plan & - & - & - & - & - & + & - & + & + & + \\
\hline Usage of template & - & - & - & - & + & + & - & + & + & - \\
\hline
\end{tabular}


1. CALIBRATE: http: / / calibrate. eun.org/merlin/index.cfm.

2. National Science Digital Library: http: / /www. nsdl . org.

3. Digital Library for Earth System Education: http: / / www. dlese org.

4. The TeachersCorner.net: http: //www. theteacherscorner.net/ lesson-plans/.

5. Virtual trip in the class: http://metodika.emokykla.1t/sites/vkk/ default.aspx.

6. Education World: http: / /www. lessonplans.com.

7. Teacher Resource Exchange: http://tre.ngfl.gov.uk/.

8. LEARN NC: http://www. learnnc.org/lessons/search?phrase= aids.

9. HOTCHALK: http: / / www . lessonplanspage.com/.

10. Theachers.net: http://teachers.net/.

The table generalizes the information on the lesson plan, given in repositories, taking into consideration the form way of lesson plan submission. It has been noticed that each repository uses only part of information elements given in learning object metadata. We shall list the most usable ones (referring to the number of repositories that use this element):

- title of the lesson plan - 10 ,

- short description -8 ,

- contributors - 10 ,

- age Range or Grade Level - 10,

- classification (subject) -9 .

Other elements are not so often repeating, they define certain peculiarities, related as usual us to specific needs. However, the presentation of namely these specific elements in the learning object metadata allow us to achieve a more accurate result of the search.

A further analysis has shown that all the lesson plans are described in the colloquial language in a free style. Four repositories present lesson plans on the internet, seven allow saving a file of the lesson plan, and four repositories suggest using templates of the lesson plan.

\section{Analysis of Templates of Lesson Plans}

After a comparative analysis of data provided by the European learning object repositories, it has been established that four (out of ten) repositories use a template of the lesson plan. These are: HOTCHALK, Virtual trip in the class (in the sequel VKK), LEARN NC and EDUCATION WORLD. Table 2 illustrates an exhaustive comparison of templates of lesson plans.

The repository HOTCHALK presents a template of the lesson plan as a recommendation, and, independent of this template, each lesson plan is structured. VKK repository presents a template of the lesson plan in ppt format: the structure off all the lesson plans is the same, however, in order to look over it, we need to use additional tool. LEARN NC 
Table 2

Comparison of lesson plan templates

\begin{tabular}{|c|c|c|c|}
\hline HOTCHALK & VKK & LEARN NC & EDUCATION WORLD \\
\hline Lesson Plan Title & Title & - & Title \\
\hline- & Brief Description & Summary of activities & Brief Description \\
\hline Concept/Topic To Teach & Subjects & - & Subjects \\
\hline- & - & $\begin{array}{l}\text { Time required for the } \\
\text { lesion }\end{array}$ & - \\
\hline General Goal(s) & Learning objectives & Learning outcomes & Objectives \\
\hline Specific Objectives & - & - & - \\
\hline Required Materials & $\begin{array}{l}\text { Learning material and } \\
\text { means }\end{array}$ & Materials/Resources & Materials Needed \\
\hline Step-By-Step Procedures & $\begin{array}{l}\text { Project context and } \\
\text { planing }\end{array}$ & Activities & Lesson Plan \\
\hline Anticipatory Set:Lead-In & - & - & - \\
\hline $\begin{array}{l}\text { Plan For Independent } \\
\text { Practice }\end{array}$ & - & - & - \\
\hline $\begin{array}{l}\text { Closure:-Reflect } \\
\text { Anticipatory Set }\end{array}$ & - & - & - \\
\hline $\begin{array}{l}\text { Assessment Based On } \\
\text { Objectives }\end{array}$ & Assessment & Assessment & Assessment \\
\hline Standards Addressed & $\begin{array}{l}\text { Conforming to the } \\
\text { curriculum }\end{array}$ & $\begin{array}{l}\text { North Carolina } \\
\text { Curriculum } \\
\text { Alignment }\end{array}$ & National Standards \\
\hline $\begin{array}{l}\text { Adaptations: For } \\
\text { Students With Learning } \\
\text { Disabilities }\end{array}$ & - & - & - \\
\hline $\begin{array}{l}\text { Extensions (For Gifted } \\
\text { Students) }\end{array}$ & - & - & - \\
\hline $\begin{array}{l}\text { Possible Connections To } \\
\text { Other Subjects }\end{array}$ & - & - & - \\
\hline- & $\begin{array}{l}\text { Age range or grade } \\
\text { level }\end{array}$ & - & Grades \\
\hline- & Keywords & - & Keywords \\
\hline- & Authors & - & $\begin{array}{l}\text { Lesson Plan Source, } \\
\text { Submitted By }\end{array}$ \\
\hline- & $\begin{array}{l}\text { List of references } \\
\text { used }\end{array}$ & - & - \\
\hline - & Pictures of a class & - & - \\
\hline- & $\begin{array}{l}\text { Survey of student's } \\
\text { work }\end{array}$ & - & - \\
\hline- & $\begin{array}{l}\text { Information on a } \\
\text { teacher or school }\end{array}$ & - & - \\
\hline
\end{tabular}

and EDUCATION WORD repositories provide a template based on internet technologies: the structure of all the lesson plans is the same, they can be quickly and comfortably looked over with a browser. 
As a generalization, note that:

- Template elements, not grounded on internet technologies, do not interact with the elements in metadata schemes, therefore information should be given twice: separately both in the template elements and in metadata elements.

- If the template of a lesson plan is not used, then the structure of each plan is different and the exhaustiveness level is indefinite.

- A part of lesson plans are presented together with the learning material, used in a lesson. The teaching material or means are 'concealed' in lesson plans - it is impossible to find them in repositories and to use them in other learning context or rely on them while applying other teaching methods.

- The whole lesson plan is comprised of the following elements: title of a lesson, age grade, learning objects, prior knowledge of user, time of learning, learning resources, other required means, teaching and learning methods, description of activities (step-by-step procedures), scope, assessment, reflection, title of the subject, correspondence to the teaching curriculum.

The analysis of templates of lesson plans illustrates that only some of the elements of template are present in all the templates of lesson plans, namely:

- learning objects:

- explicit and grounded lesson objects to be taught;

- expected results - what a student should learn or do;

- student's aims and needs;

o objects conforming the curricula;

- learning (teaching) material and means;

- step-by-step procedure of activities;

- assessment.

The main component of a lesson plan were identified. With a view to avoid information dubbing, it is reason able to separate metadata elements from description elements. The separated metadata elements could be presented and used in different learning object repositories. They are especially useful in search of lesson plans. Both components are inseparable parts of a lesson plan, because the metadata elements, in line with analysis of templates, make up the description of a lesson plan.

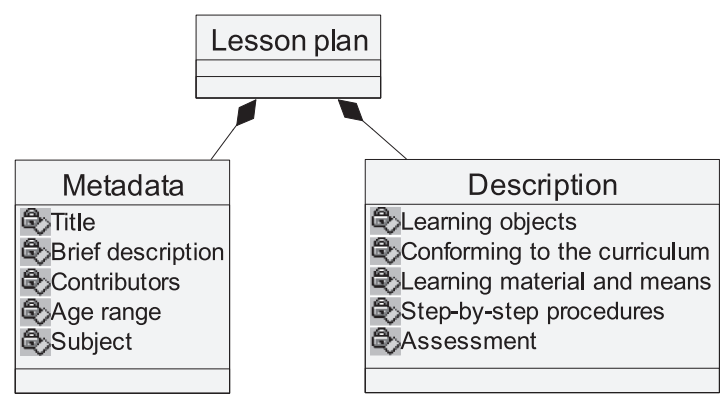

Fig. 1. Components of a lesson plan. 
Table 3

Review of metadata standards

\begin{tabular}{|c|c|c|c|}
\hline Standards & Number of elements & Application profiles & Remark \\
\hline $\begin{array}{l}\text { Learning Object } \\
\text { Metadata (IEEE } \\
\text { LOM) }\end{array}$ & $\begin{array}{l}\text { Records consist of } 80 \text { hierarchic structure } \\
\text { fields that are classified into } 9 \text { categories. } \\
\text { Divided into } 2 \text { parts: } \\
\text { - data model (1484.12.1-2002) enables to } \\
\text { achieve the maximal data modulation, } \\
\text { interoperability and applicability and is } \\
\text { capable to extend and add new data } \\
\text { elements if needed; } \\
\text { - data model (1484.12.1-2002) enables to } \\
\text { achieve the maximal data modulation, } \\
\text { interoperability and applicability and is } \\
\text { capable to extend and add new data } \\
\text { elements if needed; } \\
\text { - technical representation of metadata in } \\
\text { XML format. }\end{array}$ & $\begin{array}{l}\text { CanCore (2002); } \\
\text { UK LOM Core } \\
\text { (UK Learning ..., } \\
\text { 2003); LOM } \\
\text { LRE AP (The } \\
\text { EUN ...); } \\
\text { SingCore (Chew, } \\
\text { 2003). }\end{array}$ & $\begin{array}{l}\text { Designed to } \\
\text { describe the } \\
\text { various } \\
\text { resources. }\end{array}$ \\
\hline $\begin{array}{l}\text { Dublin Core } \\
\text { Metadata (DC) }\end{array}$ & $\begin{array}{l}\text { The standard model is of two levels: } \\
\text { simple and improved. The simple Dublin } \\
\text { Core model consists of } 15 \text { elements, } \\
\text { whole the refined one includes } 3 \text { elements } \\
\text { in addition. DC standard 2003-11-26 was } \\
\text { approved by the International } \\
\text { Standardization Organization (ISO } \\
\text { 15836:2003). }\end{array}$ & $\begin{array}{l}\text { Education } \\
\text { Network } \\
\text { Australia (EdNA) } \\
\text { (Education } \\
\text { Network ...) }\end{array}$ & $\begin{array}{l}\text { Designed to } \\
\text { describe the } \\
\text { various } \\
\text { resources. }\end{array}$ \\
\hline $\begin{array}{l}\text { MAchine- } \\
\text { Readable } \\
\text { Cataloging } \\
\text { (MARC21) }\end{array}$ & $\begin{array}{l}\text { The records are composed of three } \\
\text { elements: the record structure, the content } \\
\text { designation, and the data content of the } \\
\text { record. }\end{array}$ & - & $\begin{array}{l}\text { Designed to } \\
\text { create } \\
\text { bibliographic } \\
\text { records. }\end{array}$ \\
\hline UNIMARC & $\begin{array}{l}\text { The UNIMARC format, like MARC, } \\
\text { involves three elements of the } \\
\text { bibliographic record: the record structure, } \\
\text { the content designation and the data } \\
\text { content. The whole description consists of } \\
\text { notation definition, separators and } \\
\text { sub-field codes. }\end{array}$ & - & $\begin{array}{l}\text { Designed to } \\
\text { create } \\
\text { bibliographic } \\
\text { records. }\end{array}$ \\
\hline
\end{tabular}

\section{Analysis of LO Metadata Standards}

The key aim of metadata is to facilitate the search for LO's, assessment, retrieval and usage. LO metadata are created using standards or specifications and their applied educational models. Therefore it is necessary to determine which standard or specification will allow to reflect the peculiarities of lesson plans. One of the most frequently used metadata standards at present are as follows: Learning Object Metadata (IEEE LOM; IEEE Standard ..., 2002), Dublin Core Metadata (DC) (Dublin ... ), MAchine-Readable Cataloging (MARC21) (MARK standards ...), UNIMARC (Intenational ..., 1994). Table 3 shows systematized information on standards.

In summary, we can affirm state that DC, MARC21 and UNIMARC metadata standard models suit quite well to describe the bibliographic part of digital resource, while 
Table 4

Template of a lesson plan

\begin{tabular}{|c|c|c|c|c|c|c|c|}
\hline \multirow{2}{*}{$\begin{array}{l}\text { LOM } \\
\text { category }\end{array}$} & \multirow{2}{*}{$\begin{array}{l}\text { LOM } \\
\text { element } \\
\text { no. }\end{array}$} & \multirow{2}{*}{$\begin{array}{l}\text { LOM } \\
\text { element }\end{array}$} & \multicolumn{5}{|c|}{ Template-description of a lesson plan } \\
\hline & & & Name of field & Value of fiel & & $\begin{array}{l}\text { Multi- } \\
\text { plicity }\end{array}$ & Date type \\
\hline General & 1.2 & Title & Title of lesson & & & $0 . .1$ & LangString \\
\hline Educational & 5.7 & Typical Age Range & Age Range & $\min$ & $\max$ & $0 . .1$ & LangString \\
\hline \multirow[t]{3}{*}{ Educational } & 5.10 & Description & Objectives & Student mus & & $0 . .1$ & LangString \\
\hline & & & Expectation & & & $0 . .1$ & LangString \\
\hline & 5.12 & $\begin{array}{l}\text { Educational. } \\
\text { Prerequisites }\end{array}$ & $\begin{array}{l}\text { Necessary prior } \\
\text { knowledge of the } \\
\text { end of user }\end{array}$ & & & $0 . *(10)$ & LangString \\
\hline Educational & 5.9 & $\begin{array}{l}\text { Typical Learning } \\
\text { Time }\end{array}$ & $\begin{array}{l}\text { Learning time } \\
\text { min. }\end{array}$ & & & $0 . .1$ & $\begin{array}{l}\text { Character } \\
\text { String }\end{array}$ \\
\hline \multirow[t]{7}{*}{ Relation } & 7.1 & Kind & $\begin{array}{l}\text { Titles of digital } \\
\text { learning resources } \\
(\text { LO) used at the } \\
\text { lesson }\end{array}$ & & & $0 . .1$ & $\begin{array}{l}\text { Controlled } \\
\text { vocabulary } \\
\text { (LOM LRE) }\end{array}$ \\
\hline & 7.2 .2 & Description & & & & $0 . .1$ & LangString \\
\hline & 7.2.1.2 & Entry & $\begin{array}{l}\text { Link address to } \\
\text { LO used at the } \\
\text { lesson }\end{array}$ & http:// & & $0 . .1$ & $\begin{array}{l}\text { Character } \\
\text { String }\end{array}$ \\
\hline & & & $\begin{array}{l}\text { Other required } \\
\text { means }\end{array}$ & & & $0 . .1$ & $\begin{array}{l}\text { Character } \\
\text { String }\end{array}$ \\
\hline & & & $\begin{array}{l}\text { Description of } \\
\text { activities }\end{array}$ & Activities & $\begin{array}{l}\text { Teacher } \\
\text { and/or } \\
\text { support } \\
\text { role }\end{array}$ & 1 & $\begin{array}{l}\text { Character } \\
\text { String }\end{array}$ \\
\hline & & & Assesment & & & $0 . .1$ & $\begin{array}{l}\text { Character } \\
\text { String }\end{array}$ \\
\hline & & & $\begin{array}{l}\text { Teacher's } \\
\text { reflection or } \\
\text { comments }\end{array}$ & & & $0 . .1$ & $\begin{array}{l}\text { Character } \\
\text { String }\end{array}$ \\
\hline Educational & 5.13 & Scope & Scope & & & & $\begin{array}{l}\text { Controlled } \\
\text { vocabulary } \\
\text { (new) }\end{array}$ \\
\hline General & 1.5 & Keyword & Keywords & & & $0 . *^{*}(10)$ & LangString \\
\hline \multirow[t]{3}{*}{ Classification } & 9.1 & Purpose & Subjects & & & 1 & $\begin{array}{l}\text { Controlled } \\
\text { vocabulary } \\
\text { (LOM v.1) }\end{array}$ \\
\hline & 9.2 .2 .1 & Id & & & & $0 . .1$ & $\begin{array}{l}\text { Character } \\
\text { String }\end{array}$ \\
\hline & 9.2 .2 .2 & Entry & & & & $0 . .1$ & $\begin{array}{l}\text { Taxonomy of } \\
\text { subject }\end{array}$ \\
\hline \multirow[t]{3}{*}{ Classification } & 9.1 & Purpose & $\begin{array}{l}\text { Conforming to the } \\
\text { curriculum }\end{array}$ & & & 1 & $\begin{array}{l}\text { Controlled } \\
\text { vocabulary } \\
\text { (LOM v.1) }\end{array}$ \\
\hline & 9.2 .2 .1 & Id & & & & $0 . .1$ & $\begin{array}{l}\text { Character } \\
\text { String }\end{array}$ \\
\hline & 9.2 .2 .2 & Entry & & & & $0 . .1$ & $\begin{array}{l}\text { Taxonomy of } \\
\text { competency }\end{array}$ \\
\hline \multirow[t]{3}{*}{ Classification } & 9.1 & Purpose & $\begin{array}{l}\text { Learning } \\
\text { (teaching) } \\
\text { methods used at } \\
\text { the lesson }\end{array}$ & & & 1 & $\begin{array}{l}\text { Controlled } \\
\text { vocabulary } \\
\text { (new) }\end{array}$ \\
\hline & 9.2 .2 .1 & Id & & & & $0 . .1$ & $\begin{array}{l}\text { Character } \\
\text { String }\end{array}$ \\
\hline & 9.2 .2 .2 & Entry & & & & $0 . .1$ & $\begin{array}{l}\text { Taxonomy of } \\
\text { teaching } \\
\text { methods }\end{array}$ \\
\hline
\end{tabular}


Table 5

Elements of LOM expansion

\begin{tabular}{|c|c|c|c|c|c|}
\hline $\begin{array}{l}\text { No. of } \\
\text { element }\end{array}$ & $\begin{array}{l}\text { Category } \\
\text { title }\end{array}$ & $\begin{array}{l}\text { Element } \\
\text { title }\end{array}$ & Multiplicity & Data type & $\begin{array}{l}\text { Reason for change } \\
\text { or development }\end{array}$ \\
\hline 5.12 & Educational & $\begin{array}{l}\text { Prerequ- } \\
\text { isites (new } \\
\text { element) }\end{array}$ & $0 . . *(10)$ & LangString & $\begin{array}{l}\text { Enables us to use the } \\
\text { necessary prior knowledge } \\
\text { of a user }\end{array}$ \\
\hline 5.13 & Educational & $\begin{array}{l}\text { Scope } \\
\text { (new } \\
\text { element) }\end{array}$ & $0 . *^{*}(5)$ & $\begin{array}{l}\text { Controlled } \\
\text { vocabu- } \\
\text { lary } \\
\text { (new) }\end{array}$ & $\begin{array}{l}\text { The controlled vocabulary } \\
\text { will allow us to indicate for } \\
\text { which quantity of student the } \\
\text { activities are meant (e.g. } \\
\text { individual activity, work in } \\
\text { pairs, work in groups). }\end{array}$ \\
\hline 9.1 & Classification & Purpose & 1 & $\begin{array}{l}\text { Extended } \\
\text { Con- } \\
\text { trolled } \\
\text { vocabu- } \\
\text { lary (LRE } \\
\text { Purpose) }\end{array}$ & $\begin{array}{l}\text { Allows the reference to the } \\
\text { LO classification system } \\
\text { "Learning methods" }\end{array}$ \\
\hline 9.2.2.1 & Classification & Id & $0 . *(10)$ & $\begin{array}{l}\text { Controlled } \\
\text { vocabu- } \\
\text { lary } \\
\text { (new) }\end{array}$ & $\begin{array}{l}\text { Allows us to indicate the } \\
\text { number of ID value of the } \\
\text { vocabulary "Learning } \\
\text { methods" }\end{array}$ \\
\hline 9.2 .2 .2 & Classification & Entry & $0 . . *(10)$ & $\begin{array}{l}\text { Controlled } \\
\text { vocabu- } \\
\text { lary } \\
\text { (new) }\end{array}$ & $\begin{array}{l}\text { Allows the reference to the } \\
\text { learning methods used and } \\
\text { an expanded search for LO } \\
\text { content or didactical material } \\
\text { of a selected learning } \\
\text { method. }\end{array}$ \\
\hline
\end{tabular}

the pedagogical part only partly. Flexibility of the IEEE LOM model allows us to develop new application profiles (mandatory and freely chosen elements are defined, vocabularies and taxonomies are used), which lets us affirm that the LOM model is most often used and is able to reflect the peculiarities of lesson plans.

The main principles for the development of LO metadata standards and their application profiles are described in Duval (2002). These principles are proposed by two metadata initiatives: the Dublin Core Metadata Initiative (DCMI) and the Institute for Electrical and Electronics Engineers (IEEE) Learning Object Metadata (LOM) Working Group.

Based on the analysis of foreign science resources, metadata models and templates of lesson plans, this paper provides an extended LO metadata application profile, which presents not only theoretical principles of LO metadata standard application profile creation (Modularity, Extensibility and Refinement principles), but also practical principles (principle of standard application profile adaptation, principle of description totality and completeness, by improving the accuracy of the search result, and the subjective and objective metadata principle). 


\section{Development of Lesson Plans and Metadata Description}

The IEEE LOM standard allows the best description of lesson plan metadata. The authors proposed a template of lesson plan (Table 4), based on the IEEE LOM standard and the set main components of a lesson plan. This kind of template allows us automatically fill out the major part of LOM elements.

The table shows that only 4 elements of the lesson plan description cannot be pictured in the LO metadata model: other required means, description of activities, assessment, teacher's reflection or comments. Information given in metadata on the teaching (learning) methods used at the lesson can influence a successful search for lesson plans. Classification category 9 enables us to represent teaching (learning) methods in LO metadata standard. Therefore, we suggest to present a new controlled vocabulary "Learning methods" and to expand Educational category 5 by introducing new elements.

Advantages in the development of lesson plans by means of the technology-based template of lesson plans (Table 4):

- Development of lesson plans does not require additional software.

- Part of information consists of IEEE LOM element data. That saves teacher's time when preparing metadata.

A disadvantage is that a part of activity description remains nonstandardized.

Table 6 presents metadata that are not included into the description-template of a lesson plan, however they are submitted when describing a lesson plan in the repository.

Table 6

Metadata of a lesson plan

\begin{tabular}{lll}
\hline LOM element & Multiplicity & Data type \\
\hline 1.4 General.Description & $0 . *^{*}(10)$ & LangString \\
2.3.1 LifeCycle.Contribute.Role & 1 & Controlled vocabulary (LOMv1.0) \\
2.3.2 Life Cycle.Contribute.Entity & $1 . .^{*}(40)$ & Character String \\
1.3 General.Language & $1 . *^{*}(10)$ & Character String \\
3.4 Meta-Metadata.Language & $1 . *^{*}(10)$ & Character String \\
3.4 Meta-Metadata.Contribute. Role & $0 . .1$ & Controlled vocabulary (LOMv1.0) \\
3.4 Meta-Metadata.Contribute.Entity & $0 . .1$ & Character String \\
5.2 Educational.Learning Resource Type & $0 . . *(10)$ & Controlled vocabulary (LOM LRE) \\
5.5 Educational.IntendedEndUser Role & $0 . .7$ & VocabularyTerm (LOM LRE) \\
7. Relation & $0 . *^{*}(100)$ & \\
7.1 Relation.Kind & $0 . .1$ & Controlled vocabulary (LOM LRE) \\
7.2.2 Relation.Description & $0 . .1$ & LangString \\
7.2.1.2 Relation.Entry & $0 . .1$ & Character String \\
5.6 Educational.Context & $0 . .12$ & Controlled vocabulary (LOM LRE) \\
6.1 Rights.Cost & 1 & Controlled vocabulary (LOMv1.0) \\
6.2 Rights.Copyrightandotherrestrictions & 1 & Controlled vocabulary (LOMv1.0) \\
6.3 Rights. Description & $0 . .1$ & LangString \\
\hline
\end{tabular}


These are data elements that will allow us to submit a brief description of a lesson plan, author contributor, lesson plan and description language, indicate relations with the relevant teaching plans, to refer to the context and the LO type (lesson plan) as well as the necessary information on the copyrights and restrictions on the lesson plan.

\section{Conclusion}

The analysis made has shown that lesson plans are described by the colloquial language of free style which determines a different description of structure and the exhaustiveness level. Metadata elements comprise a fair amount of the lesson plan description elements. In a separate preparation of lesson plans and their metadata, the time period of their development and description is increased and human resources are used inefficiently.

After the analysis, the main components of lesson plan formation and description have been established on the basis of which technology-based lesson plan templates for improving the LO metadata standard application profile and the educational LOM model have been expanded. Such a template automatically distinguishes metadata elements and enables a flexible use of information on lesson plans and search.

\section{References}

CanCore (2002). Learning Object Metadata, version 1.1, CanCore Initiative, Athabasca University, Edmonton, Alberta. Available: http: / /www. cancore.ca/guidelines / CanCore\%20Guidelines\% 20version\%201.1.doc.

Cheon, J-P., Paek, J-M., Han, S.-G., Lee, Ch.-H. (2002). Automated lesson planner system for ICT education. In: Computers in Education, Proc. Int. Conference, Vol. 1, 485-489.

Chew, L.K. (2003). Metadata Implementations in Singapore. Available: http: / / pnclink.org/annual / annual2003/programe/presenpdf/110821.pdf.

Dagienè, V., Kurilovas, E. (2008). Informacinès technologijos švietime: patirtis ir analizè. Monografija. Vilnius, Matematikos ir informatikos institutas.

Dublin Core Metadata Initiative (2010). DCMI Metadata Terms. Available:

http: / / dublincore.org/documents / dcmi-terms /.

Duval, E. et al. (2002). Metadata principles and practicalities. D-lib Magazine, 8(4), 1-16.

Education Network Australia (EdNA). Available:

http: / /www. educationau. edu.au/jahia/

webdav/site/myjahiasite/shared/papers/edna_metadata.pdf.

IEEE Standard for Learning Object Metadata. Available:

http: / / ieeexplore. ieee. org/servlet/opac ? punumber $=8032$.

International Federation of Library Associations and Institutions (1994). UMIMARC Manual: Bibliographic Format 1994. Available: http: / /www. ifla.org/VI/3/p1996-1/sec-uni.htm.

Jevsikova, T., Kurilovas, E. (2006). European learning resource exchange: policy and practice. In: Proc. of the 2nd International Conference "Informatics in Secondary Schools: Evolution and Perspectives". Vilnius, Lithuania. Selected papers, TEV, 670-676.

Jovaiša, L. (1993). Pedagogikos terminai. Kaunas, Šviesa.

Kouno, S., Yokoyama S., Nakamura, N., Yonezawa, N., Miyadera, Y. (2002). Development of generator for lesson plan making support systems. Computers in Education, 2, 3-6 Dec. 1181-1185.

MARC standards - Library of Congress Network Development and .MARC Standards Office. MARC 21 Format for Bibliographic Data (1994). Available:

http: //www. loc.gov/marc/bibliographic/ecbdlist.html. 
Rajeckas, V. (1999). Mokymo organizavimas. Kaunas, Šviesa.

Roselli, T., Rossano, V. (2006). Describing learning scenarios to share teaching experiences. In: Information Technology Based Higher Education and Training, ITHET '06. 7th International Conference, 166-172.

Slotkiené, A. (2009). Aktyvaus mokymosi objekto projektavimo metodas ir jo tyrimas. Kauno technologijos universitetas, daktaro disertacija.

Tate M., Hoshek, D. (2009). A model for the effective management of re-usable learning objects. Interdisciplinary Journal of E-Learning and Learning Objects, 5.

The EUN Learning Resource Exchange LOM Application Profile. Available: http://fire.eun.org/LRE-AP-3.0.pdf.

UK Learning Object Metadata Core (2003). Available: http://zope.cetis.ac.uk/profiles/uklomcore/uklomcore_v0p1.doc.

Verbert, K., Duval, E. (2004) Towards a global component architecture for learning objects: a comparative analysis of learning object content models. In: Proc. of the ED-MEDIA, World Conference on Educational Multimedia, Hypermedia and Telecommunications, 202-208.

Verbert, K., Jovanovic, J., Gaševic, D., Duval, E., Meire, M. (2005). Towards a clobal component architechture for learning objects: a slide presentation framework. In: Proc. of World Conference on Educational Multimedia, Hypermedia and Telecommunications, Chesapeake, VA, AACE, 1429-1436.

Wiley, D. (2000). Connecting Learning Objects to Instructional design Theory: A Definition, a Metaphor, and a Taxonomy. Utah State University. Available: http://www.reusability.org/read/.

V. Dagienè is head of department at the Institute of Mathematics and Informatics. She has published over 150 scientific papers, written more than 60 textbooks in the field of informatics for secondary education and teacher training. She has been chair of Lithuanian Olympiads in Informatics for many years, organized Baltic Olympiad in Informatics in 1997, 2002, and 2005, and established the International Contest on Informatics and Computer Fluency "Bebras". She is vice chair of the IFIP (International Federation for Information Processing) TC3 Committee on Education, and member of the International Committee on Olympiads in Informatics (2006-2012).

S. Kubilinskienė is doctoral student at Institute of Mathematics and Informatics. She graduated from Vilnius Pedagogical University with a master of informatics and mathematics in 1996. Her research interests include the management and reuse of digital learning resources, metadata specification and standards, development of learning object and related software, learning management systems and environments.

\section{Pamokos planas - svarbus mokymosi proceso metodinis komponentas}

\section{Svetlana KUBILINSKIENĖ, Valentina DAGIENĖ}

Straipsnio tikslas - išnagrinèti esamą situaciją ir pasiūlyti, kaip informacinès technologijos galètụ talkinti pamokụ planams kurti, juos kaupti, ieškoti šitaip užtikrinant jų efektyvų taikymą. Atskleidžiama pamokos planų rengimo ir aprašymo problematika, analizuojama Europos mokymo objektu saugyklose kaupiama informacija ir pamokos planų rengimo šablonai. Remiantis mokymosi objektų metaduomenų standarto taikymo modelio elementų tobulinimo principais, atliktos analizès rezultatais, nustatytais pagrindiniais pamoku planų rengimo ir aprašymo komponentais, siūlomas technologijomis grisstas pamokos planų kūrimo šablonas ir išplèstas metaduomenų standarto taikomasis modelis. Sistemingas pamoku planų ir aprašu pateikimas sudaro sąlygas pedagogams pakartotinai naudoti didaktinius išteklius (pamoku planus) kaip veiksmingą mokymosi priemonę mokykloje. Aptariama, kaip išteklių saugyklą publikuotą mokytojų veiklos gerają patirti efektyviau panaudoti skirtinguose mokymosi scenarijuose. 